\title{
ANALISIS BEBAN GEMPA TERHADAP KEKUATAN STRUKTUR BANGUNAN MULTI DEGRRE OF FREEDOME
}

\author{
Almufid, ST., MT \\ Fakultas Teknik Sipil \\ Universitas Muhammadiyah Tangerang \\ E-mail: almufid_st@yahoo.com
}

\begin{abstract}
Structural analysis is planned phases of a building, especially the high buildings. In the analysis of the structure required to facilitate the modeling calculations reflect actual conditions in the field, both in structure and in the loaded. Because almost all parts of Indonesia, including the earthquake-prone areas is a challenge for civil engineering planning in order to design earthquakeresistant buildings. Indonesia has many experienced tremendous earthquake

Writing this proposal is intended to be able to know the strength and structure of the response Strength multi degree of freedome, on soft ground, located in Tangerang when worn earthquake lateral loads, analysis is done with the help of the SAP program in 2000 ver.15, to get the style - the style such as: the base shear force, lateral force level, rolling moment and lateral deviation.

Dynamic analysis was conducted using the response spectrum analysis, mass modeling performed with a lump mass models, the sum of the response variance is reviewed with some combinations, such as: CQC, SRSS and ABSSUM.
\end{abstract}

Keywords: Building Multi Degrre of Freedome, response spectrum analysis, dynamic loads, with the use of the method; CQC, SRSS, ABSSUM

\section{PENDAHULUAN}

\subsection{Latar Belakang}

Analisis struktur merupakan hal yang sangat menentukan dalam tahap merancang suatu bangunan. Untuk itu pemodelan matematis pada analisis struktur harus mencerminkan kondisi sebenarnya, baik dalam konfigurasi struktur serta pembebanan. Dalam penulisan ini, penulis membandingkan analisis beban lateral yang disebabkan dari beban gempa secara manual dan dengan menggunakan program bantu SAP 2000 ver.15.

Karena hampir seluruh wilayah Indonesia termasuk wilayah rawan gempa maka merupakan tantangan bagi teknik sipil untuk dapat mendesain bangunan yang tahan gempa. Indonesia sudah banyak mengalami bencana gempa yang luar biasa, sebagai contoh gempa bumi yang terjadi di daerah Padang pada bulan September 2009. Dimana gedung-gedung bertingkat banyak mengalami kerusakan bahkan rubuh yang hanya menyisakan bangkai bangunannya saja. Akibat dari peristiwa tersebut maka menimbulkan banyaknya korban jiwa yang berjatuhan. Untuk itu perencanaan pembangunan gedung di daerah rawan gempa harus dengan benar, agar dapat meminimalisir korban yang ada.

\subsection{Permasalahan Penelitian}

Untuk dapat mendesain dan merencanakan bangunan yang tahan terhadap beban Dinamik pada struktur bangunan Multi Degrre of Freedome (gempa bumi) maka sudah banyak digunakan program bantu yang digunakan oleh insinyur teknik sipil akhir-akhir ini seperti ETABS, STADPRO, SAP, SAFE, dll. Program-program ini memiliki fungsinya masing-masing, program tersebut digunakan untuk dapat mempermudah pada saat perhitungan dan desain bangunan. Akan tetapi penggunaan program harus didasari dengan perhitungan dan pembuktian analitis secara manual yang sesuai dengan peraturan 
yang ada dan dapat dibuktikan agar penggunaan program tersebut tidak salah diterapkan. Setidaknya dengan perhitungan manual dapat membayangkan atau membandingkan penggunaan program agar dapat dijadikan acuan.

\subsection{Tujuan Analis Struktur Beban Dinamik}

Menghitung dan desain pada bangunan Multi Degree Of Freedome dengan benar dan kuat terhadap beban Dynamic dengan menggunakan perhitungan dengan penggunaan program pada batasan-batasan yang ditentukan dan Mempelajari juga Mengaplikasikan program sebagai program bantu penyelesaian masalah desain dalam dunia perencanaan teknik sipil.

\subsection{Pembahasan Permodelan Struktur}

Ruang lingkup pembahasan beban

Dinamik ini meliputi:

Pemodelan dan desain awal struktur bangunan beton bertulang

- Klasifikasi gedung bertingkat yang berfungsi sebagai kantor.

Gedung terletak di wilayah Jakarta dengan kondisi tanah lunak (mengacu pada SNI 03-1726-2012 dan peta gempa baru Juni 2010).

- Pembebanan gempa sesuai dengan peraturan SNI 03-2847-2012, dan dengan peraturan ASCE 7-10 dan IBC 2009.

- Perhitungan manual untuk mencari waktu getar alami atau periode bangunan.

Perbandingan penggunaan SRSS (Square Root of the Sum of Squares), CQC (Complete Quadratic Combination). ABSSUM (Absolut Sum), yang terdapat pada contoh program ETABS 9.2 dengan perhitungan manual.sesuai SNI 1726:2002 dan SNI 1726:2012

\section{KAJIAN LITERATUR}

2.1 Desain pada Program SAP 2000 Ver. 15

SAP 2000: Structur Anlysis Program merupakan salah satu program yang dikembangkan oleh CSI yang berasal dari Berkeley, California, Amerika Serikat. Selain SAP 2000, CSI juga mengeluarkan program ETABS dan juga SAFE. Program tersebut memiliki kegunaannya masing-masing dalam mendesain dan menganalisis suatu struktur. Program ini sangat berguna bagi dunia teknik sipil karena dapat membantu dalam mendesain dan menganalisa suatu struktur.

Pemodelan struktur secara umum dapat dibagi menjadi pemodelan struktur 2D dan pemodelan struktur 3D, untuk analisis 2D hanya ditinjau sebagai struktur dalam, bidang $X Y$, dengan demikian struktur tidak mampu bergerak kearah $Z$, sehingga struktur 2D lebih kaku dibandingkan dengan struktur 3D sedangkan struktur ruang (struktur 3D) mampu bergerak ke segala arah $: X, Y$, dan Z.

Secara garis besar tahapan dalam mendesain dan menganalisis struktur pada program SAP 2000 Ver. 15 adalah:

1. Menentukan geometri model struktur

2. Mendefinisikan data struktur

- Data material

- Data penampang

- Data beban

- Data kombinasi pembebanan

3. Menetapkan data ke model struktur

- menetapkan data penampang

- menetapkan beban yang bekerja

4. Memeriksa input data

5. Melakukan analisis

6. Melakukan desain struktur

7. Melakukan desain ulang bila perlu

Diagram alir untuk pemodelan struktur dengan program bantu SAP 2000 dapat dilihat disamping berikut. 


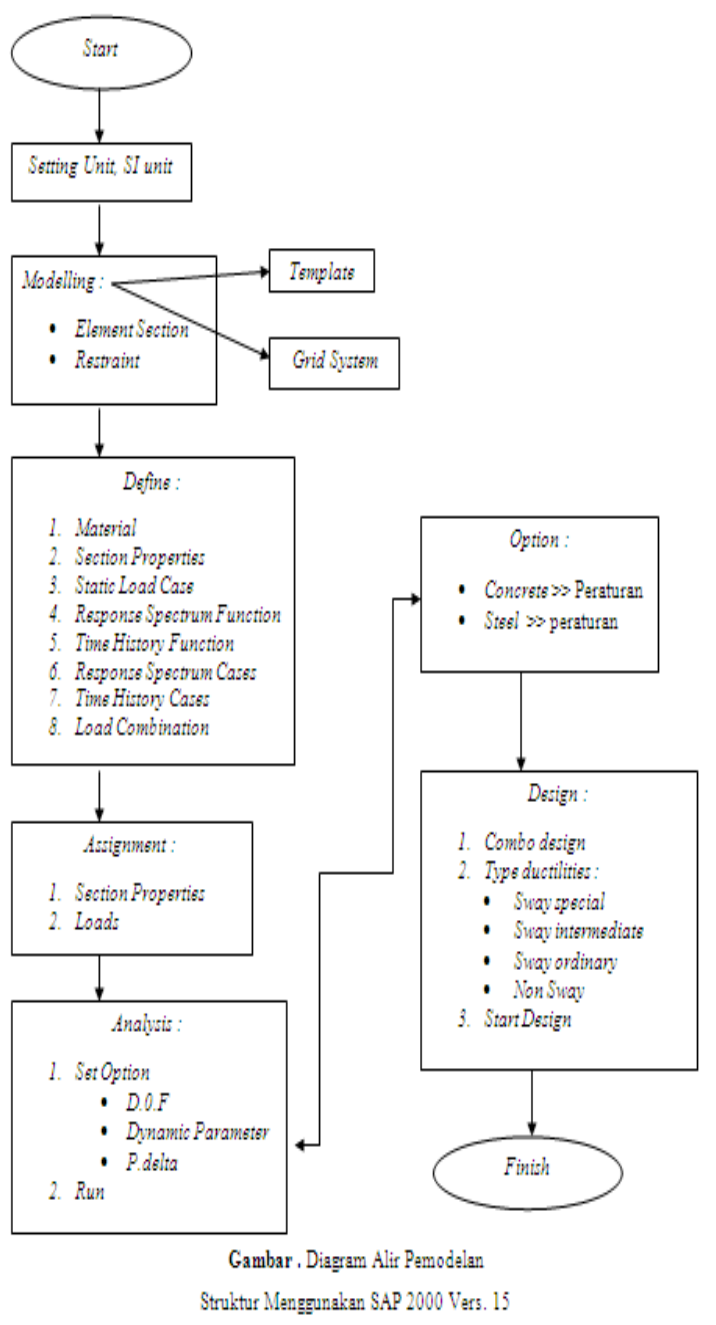

\subsection{Konfigurasi Struktur}

Berdasarkan Standar Standar Nasional Indonesia SNI 03-1726-2002 dan SNI 031726-2012 tentang Tata Cara Perencanaan Ketahanan Gempa untuk Rumah dan Gedung, struktur bangunan gedung dibedakan kedalam dua jenis, yaitu:

1. Struktur bangunan gedung beraturan.

2. Struktur bangunan gedung tidak beraturan.

Struktur bangunan gedung ditetapkan sebagai struktur bangunan gedung beraturan apabila memenuhi ketentuan sebagai berikut:

Tinggi struktur bangunan gedung diukur dari taraf penjepitan lateral tidak lebih dari 10 tingkat atau 40 meter.

Denah struktur bangunan gedung adalah persegi panjang. Apabila terdapat tonjolan maka panjang tonjolan tersebut tidak lebih dari $25 \%$ dari ukuran terbesar denah struktur bangunan gedung dalam arah tonjolan tersebut dan apabila terdapat coakan sudut maka panjang sisi coakan tersebut tidak lebih dari $15 \%$ dari ukuran terbesar denah struktur bangunan gedung dalam arah coakan tersebut.

Sistem struktur bangunan gedung tidak menunjukkan loncatan bidang muka dan kalaupun mempunyai loncatan bidang muka, maka ukuran dari denah struktur bagian gedung yang menjulang dalam masingmasing arah tidak kurang dari $75 \%$ dari ukuran terbesar denah struktur bagian gedung sebelah bawahnya. Struktur rumah atap yang tingginya tidak lebih dari dua tingkat tidak perlu dianggap menyebabkan adanya loncatan bidang muka.

Memiliki kekakuan lateral yang beraturan tanpa adanya tingkat lunak. Tingkat lunak adalah suatu tingkat dimana kekakuan lateralnya adalah kurang dari $70 \%$ kekakuan lateral tingkat di atasnya atau kurang dari 80 $\%$ kekakuan lateral rata-rata tiga tingkat di atasnya.

Memiliki berat lantai tingkat yang beraturan, artinya setiap lantai tingkat memiliki berat yang tidak lebih dari $150 \%$ dari berat lantai tingkat di atasnya atau di bawahnya. Berat atap atau rumah atap tidak perlu memenuhi ketentuan ini.

Memiliki unsur-unsur vertikal dari sistem pemikul beban lateral yang menerus tanpa perpindahan titik beratnya, kecuali bila perpindahan tersebut tidak lebih dari setengah ukuran unsur dalam arah perpindahan tersebut.

Memiliki lantai tingkat yang menerus tanpa lubang atau bukaan yang luasnya lebih dari $50 \%$ luas seluruh lantai tingkat. Kalaupun ada lantai tingkat dengan lubang atau bukaan seperti itu, jumlahnya tidak boleh melebihi $20 \%$ dari jumlah lantai tingkat seluruhnya.

Struktur bangunan gedung yang tidak memenuhi ketentuan tersebut diatas, ditetapkan sebagai struktur bangunan tidak beraturan. Untuk struktur gedung tidak beraturan, pengaruh gempa rencana harus ditinjau sebagai pengaruh pembebanan gempa dinamik, sehingga analisisnya harus dilakukan berdasarkan analisis respon dinamik. 


\subsection{Analisis Bangunan Tahan Gempa}

Dalam menghitung beban gempa yang di asumsikan ditahan oleh struktur bangunan. Maka bangunan yang terkena oleh beban gempa akan memiliki suatu respon dinamis.

Secara umum analisis perhitungan respon suatu bangunan dibagi menjadi empat, yaitu:

Perhitungan statik ekuivalen

Perhitungan beban dorong static: static pushover analysis)

- Perhitungan analisa ragam spektrum respon (Response spectrum analysis)

Perhitungan respon riwayat waktu:Time history analysis )

Jumlah ragam getar yang ditinjau dalam penjumlahan respons ragam harus sedemikian rupa sehingga partisipasi massa ragam efektif dalam menghasilkan respons total harus mencapai sekurang-kurangnya 90 \% (SNI 03-1726-2002). Dan (SNI 03-17262012)

Dalam SNI 03-1726-2002 dan (SNI 031726-2012) disyaratkan nilai akhir res-pons dinamik struktur bangunan gedung terhadap pembebanan gempa nominal dalam suatu arah tertentu tidak boleh diambil kurang dari $80 \%$ nilai respons ragam yang pertama, sedangkan menurut ASCE 7-10 tidak boleh kurang dari $85 \%$.

Dalam penulisan ini menggunakan response spectrum analysis untuk mencari respon dinamis bangunan yaitu suatu cara analisis untuk menentukan respons dinamik struktur yang berprilaku elastik terhadap pengaruh suatu gempa melalui suatu metoda analisis, dimana respon dinamik maksimum masing-masing ragamnya didapat melalui spektrum respons gempa rencana.

\section{METODE PENELITIAN}

Pada suatu struktur terdapat tiga macam yang berpengaruh pada getaran yaitu massa, kekakuan dan redaman. Ketiga hal itu biasa disebut dengan karakteristik bangunan.

\section{Massa}

Suatu struktur bertingkat akan banyak memiliki derajat kebebasan yang berarti memiliki massa tertentu. Massa pada suatu bangunan diasumsikan berada pada masingmasing lantainya. Terdapat dua pemodelan pokok yang terdapat dalam memodelkan atau mendeskripsikan massa struktur:

\section{- Model Lump Mass}

Model ini disimplifikasi dimana massa dianggap menggumpal pada tempat tempat (/ump mass) join atau tempat tertentu. Jadi, banyak tingkat bangunan di asumsikan mempunyai satu pusat massa pada tiap-tiap tingkatannya. Oleh karena itu banyaknya derajat kebebasan ditentukan dengan tingkat bangunan yang ada. Matriks massa hanya ada pada bagian diagonal utama saja.

$[\mathrm{m}]=$ matriks massa

$\left[\begin{array}{cccc}\mathrm{m}_{1} & 0 & 0 & 0 \\ 0 & \mathrm{~m}_{2} & 0 & 0 \\ 0 & 0 & \mathrm{~m}_{3} & 0 \\ 0 & 0 & 0 & \mathrm{~m}_{\mathrm{n}}\end{array}\right]$

\section{Model Consistent Mass Matrix}

Model ini adalah model kedua dari kemungkinan pemodelan massa struktur. Pada model consistent mass matrix ini bahwa elemen struktur akan berdeformasi menurut bentuk fungsi :shape function) tertentu. Apabila tiga derajat kebebasan diperhitungkan :horizontal, vertikal, dan rotasi) pada setiap node maka akan menghasilkan full-populated consistent matrix yang artinya suatu matrix yang offdiagonal tidak sama dengan nol.

Untuk struktur bangunan bertingkat banyak yang massanya terkonsentrasi pada tiap-tiap lantai, pemodelan lump mass masih cukup akurat. Untuk itu pada perhitungan sistem berderajat banyak :MDOF ) akan menggunakan pemodelan lump mass.

\section{Kekakuan}

Kekakuan merupakan salah satu karakteristik yang penting selain massa dan redaman. Antara kekakuan dan massa mempunyai hubungan yang biasa disebut eigenproblem atau karakteristik diri. Hubungan tersebut akan menentukan nilai dari natural circular frequency $(\omega)$ dan periode bangunan $(T)$.

Dalam prinsip bangunan geser (Shear Building) dimana balok dianggap tetap baik 
sesudah ataupun sebelum terjadi pergoyangan akibat dari beban dinamis serta menyatu pada pelat dan dianggap kaku. Sedangkan pelat yang dianggap memikul massa pada tiap tingkatan lantai yang kemudian akan di transfer beban-beban yang bekerja melalui kolom, sehingga kolom mempunyai kekakuan tertentu. Dalam mendesain bangunan tahan gempa diguna-kan prinsip (Strong column weak beams) dimana dikehendaki kondisi kolom lebih kuat diabandingkan baloknya, tetapi memiliki rasio tingkat kekakuan yang berbeda.

Besarnya kekakuan untuk suatu kolom dengan asumsi balok penghubungnya sangat kaku adalah

Untuk kolom dengan ujung jepit-jepit:

$$
\mathrm{K}=\frac{12 \mathrm{EI}_{\mathrm{i}}}{\mathrm{L}_{\mathrm{i}}^{3}}
$$

Untuk kolom dengan ujung jepit-sendi:

$\mathrm{K}=\frac{3 \mathrm{EI}_{\mathrm{i}}}{\mathrm{L}_{\mathrm{i}}^{3}}$

Untuk dinding kantilever :

$\mathrm{K}=\frac{3 \mathrm{EI}_{\mathrm{i}}}{\left.\mathrm{h}^{3}[1+0.6: 1+\mathrm{v}) \frac{\mathrm{d}^{2}}{\mathrm{~h}^{2}}\right]}$

Untuk batang diagonal :

$$
\mathrm{K}=\frac{\mathrm{AE}}{\mathrm{L}} \cos ^{2} \theta
$$

Dimana:

$\mathrm{K}=$ kekakuan kolom

$\mathrm{E}=$ Modulus elastisitas bahan kolom

$\mathrm{I}=$ Momen inersia penampang kolom ke $\mathrm{i}$

$\mathrm{L}=$ Panjang kolom ke $\mathrm{i}$

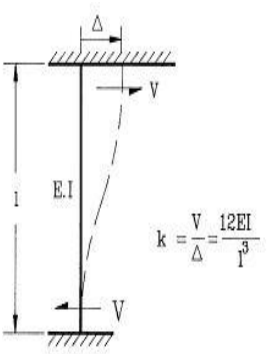

a) FIXED-FIXED

COLUMN

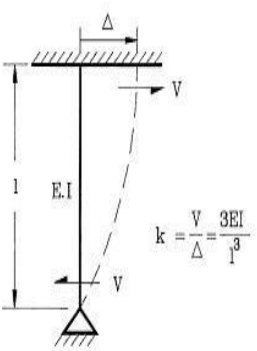

c) FIXED-PINNED COLUMN

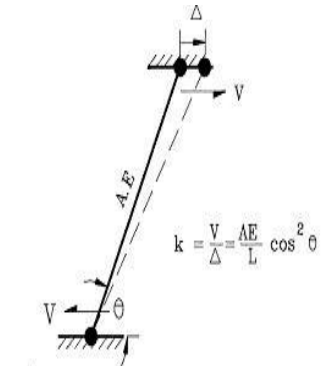

B) DIAGONAL BRACE

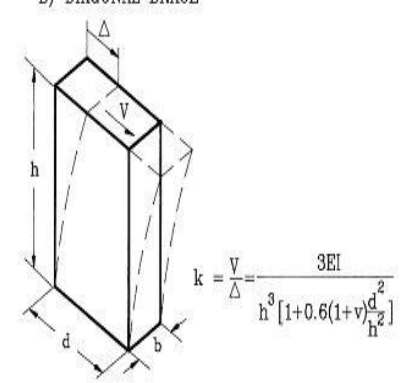

d) CANTILEVER WALL.
Gambar Kekakuan elemen akibat gaya lateral

\section{Redaman}

Redaman adalah peristiwa pelepasan energi oleh suatu struktur akibat terjadinya suatu getaran atau gerakan pada struktur tersebut. Gerakan itu terjadi antara lain akibat adanya kondisi struktur pada saat kondisi plastis atau inelastis. Kemudian juga terjadi akibat pergeseran struktur akibat dari beban dinamis. Karena redaman berfungsi melepaskan energi maka akan mengurangi respon dari struktur.

\section{Derajat Kebebasan (Degree Of Free- dom, DOF)}

Jumlah derajat kebebasan adalah simplifikasi jumlah minimum koordinat yang diperlukan untuk menyatakan posisi suatu massa pada saat tertentu. Pada problem dinamik dapat disederhanakan bahwa setiap massa umumnya hanya dihitung berpindah tempat dalam satu arah saja yaitu arah horizontal. Bangunan satu tingkat dalam kondisi dua dimensi dianggap hanya mempunyai satu derajat kebebasan tunggal (single degree of freedom, SDOF) dan bangunan dengan $\mathrm{N}$ tingkat mempunyai $\mathrm{N}$ derajat kebebasan atau struktur dengan banyak derajat kebebasan (multi degree of freedom, MDOF). Sehingga pada setiap tingkat terdapat hanya satu derajat 
kebebasan saja. Model ini dinamakan bangunan geser (shear building).
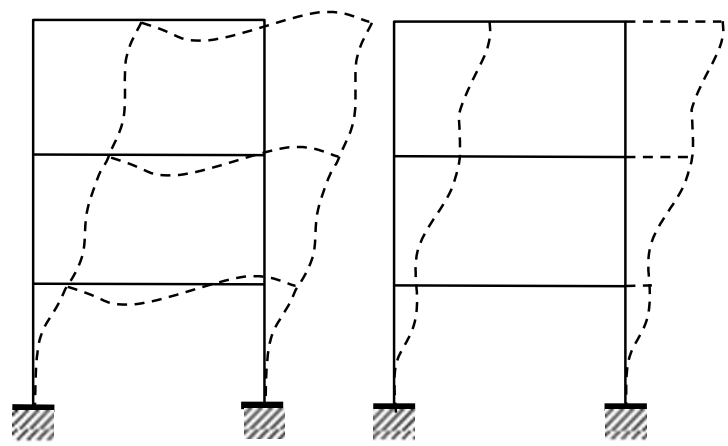

a. Shear Building

b. Moment Resisting Building

Gambar Model bangunan gedung bertingkat

Kegunaan dari degree of freedom adalah untuk mencari displacement, rotation serta gaya-gaya dalam yang bekerja pada struktur akibat beban yang bekekerja pada struktur tersebut.

- Sistem Berderajat Tunggal (SDOF, Single Degree of freedom)

Sistem berderajat tunggal merupakan simplifikasi bangunan yang mempunyai jumlah tingkatan hanya satu lantai sehingga diasumsikan hanya memiliki satu derajat kebebasan.

\section{$\mathrm{m}_{1}$}

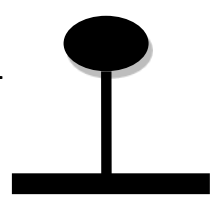

Gambar Model lump mass satu derajat kebebasan.

Persamaan kesetimbangan berdasarkan prinsip d' Alembert:

$f_{I}(t)+f_{D}(t)+f_{S}(t)=p(t)$

dimana:

$$
\begin{aligned}
& \mathrm{f}_{\mathrm{I}}(\mathrm{t})=\text { Gaya inersia }=\mathrm{m} \cdot \ddot{\mathrm{u}}(\mathrm{t}) \\
& \mathrm{f}_{\mathrm{D}}(\mathrm{t})=\text { Gaya damping }=\text { c.ú }(\mathrm{t}) \\
& \mathrm{f}_{\mathrm{S}}(\mathrm{t})=\text { Gaya pegas } \quad=\text { k.u }(\mathrm{t})
\end{aligned}
$$

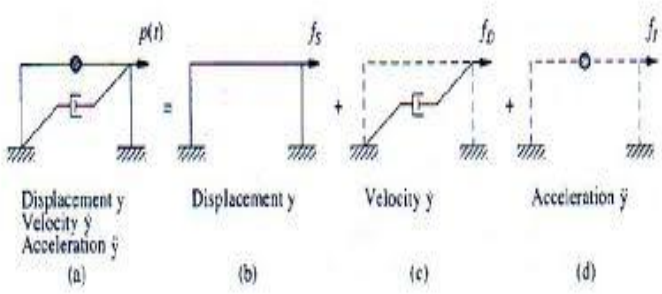

Gambar. Struktur dengan satu derajat kebebasan

Persamaan dasar gerak yang dipengaruhi oleh pergerakan bidang datar:

m.ü (t) + c.ú $(t)+k . u(t)=0$

dimana:

$\ddot{\mathrm{u}}^{\mathrm{t}}(\mathrm{t})=\ddot{\mathrm{u}}(\mathrm{t})+\ddot{\mathrm{u}}_{\mathrm{g}}(\mathrm{t})$

$\mathrm{m} . \ddot{\mathrm{u}}(\mathrm{t})+\mathrm{m} \cdot \ddot{\mathrm{u}}_{\mathrm{g}}(\mathrm{t})+\mathrm{c} \cdot \dot{u}(\mathrm{t})+\mathrm{k} \cdot \mathrm{u}(\mathrm{t})=0$

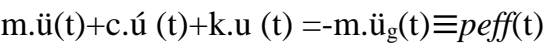
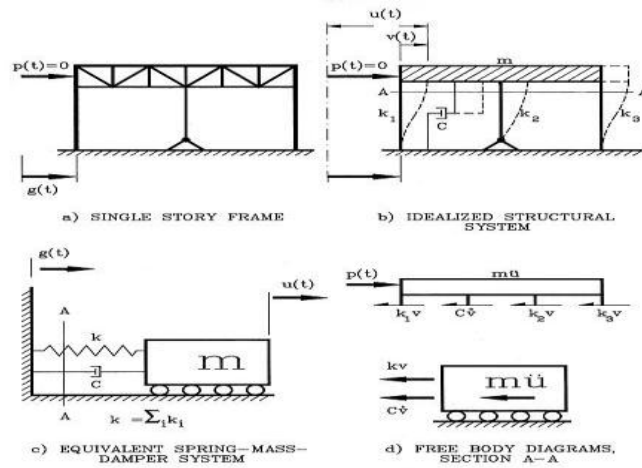

Gambar . Struktur SDOF akibat base motion (Sumber: Naeim, 2002)

Persamaan diferensial relatif akibat dari gaya inersia, gaya damping dan gaya pegas yang ketiganya timbul akibat dari simpangan relatif. Ruas kanan pada persamaan disebut dengan beban gempa efektif atau gerakan tanah efektif.

- $\quad$ Sistem Berderajat Banyak (MDOF, Multi Degree of freedom)

MDOF atau sistem berderajat banyak merupakan simplifikasi bangunan yang mempunyai jumlah tingkatan $\mathrm{N}$ tingkat, sehingga diasumsikan memiliki $\mathrm{N}$ derajat kebebasan. Persamaan pada sistem berderajat banyak hampir sama dengan prinsip sistem berderajat tunggal, tetap menggunakan model bangunan geser :shear building).

Sebagai contoh pada bangunan bertingkat 4 dibawah ini, di asumsikan jumlah lantai menggumpal (lump mass) pada titik-titik atau join tertentu. Sehingga banyaknya 
tingkat bangunan disimplifikasi memiliki satu untuk tiap tingkatannya.

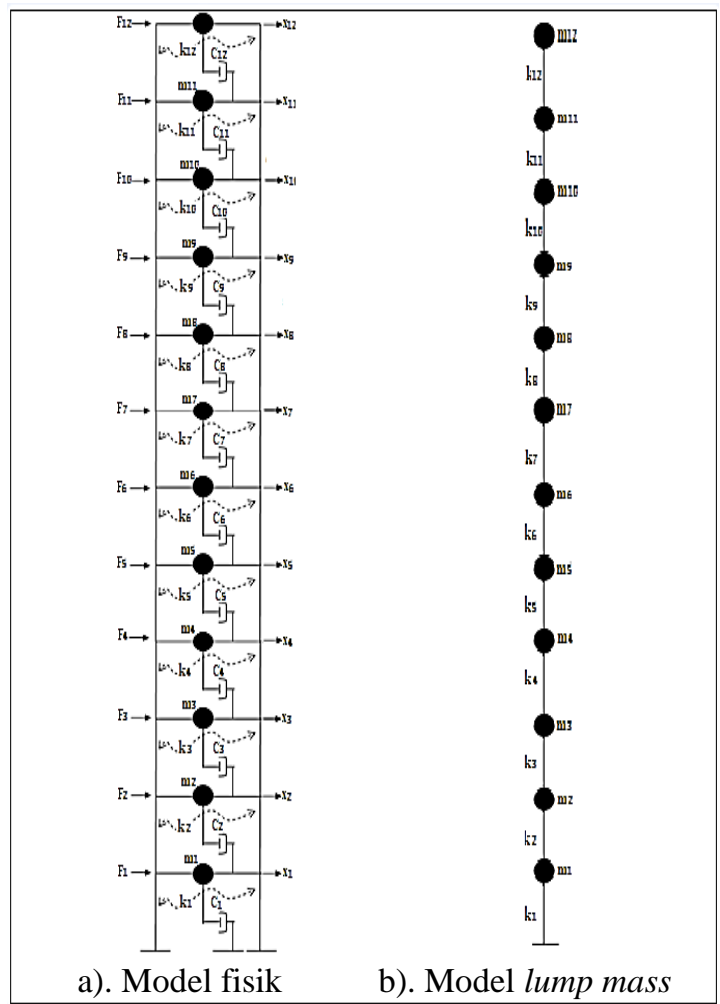

c). Model matematik

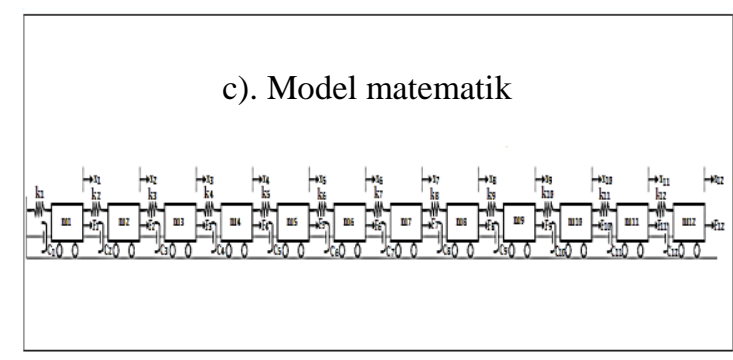

Gambar Struktur dengan derajat kebebasan banyak

Persamaan diferensial gerakan adalah ungkapan secara matematis yang mendefinisikan perpindahan dinamis dari suatui sistem struktur. Penyelesaian dari persamaan tersebut adalah memberikan suatu gambaran yang lengkap dari respon suatu sistem struktur berdasarkan fungsi dari waktu. Cara persamaan berdasarkan prinsip d'Alembert, yaitu pada suatu massa bekerja gaya inersia yang sebanding dengan percepatannya tetapi dalam arah berlawanan.
Persamaan gerak:

$\mathbf{f}_{\mathrm{I}}(\mathbf{t})+\mathbf{f D}_{\mathrm{D}}(\mathbf{t})+\mathbf{f S}_{\mathrm{S}}(\mathbf{t})=\mathbf{p}(\mathbf{t})$

3 persamaan differensial yang coupled

\subsection{Pengaruh Gaya Inersia $\left\{f_{I}\right\}$}

Besarnya gaya-gaya inersia ini tergantung dari berat bangunannya, semakin ringan berarti semakin kecil gaya inersia yang bekerja dalam elemen struktur, selain terhadap fungsi dari massa, gaya inersia juga erat hubungannya terhadap gaya gempa. Tanah dasar yang bergerak tidak beraturan akibat dari gaya gempa, mengakibatkan percepatan tanah yang juga mempengaruhi gaya inersia

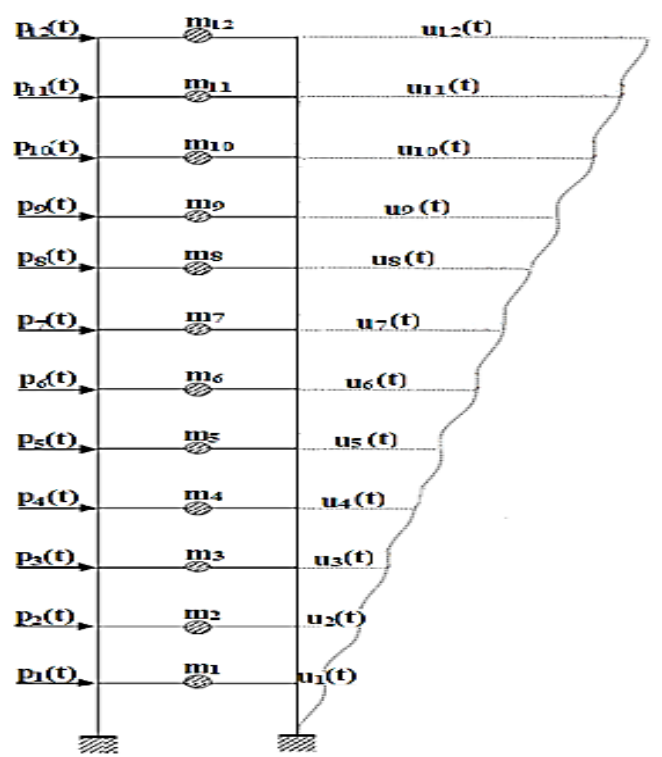

Gambar Model bangunan geser untuk struktur berderajat 12

$\left\{\mathbf{f}_{\mathbf{I}}\right\}=[\mathbf{m}]\{\ddot{\mathbf{u}}\}$

Dimana:
[m] = Matriks massa
$\{\ddot{\mathbf{u}}\}=$ Vektor percepatan
$\{\mathbf{f s}\} \quad=[\mathbf{k}] \quad .\{\mathbf{u}\}$

Dimana:

[k] = Matriks kekakuan

$\{\mathbf{u}\}=$ Vektor simpangan

Catatan : $k_{12}$ adalah besarnya gaya lateral pada massa 1 , bila diadakan perpindahan lateral pada massa 2 sebesar satu 
satuan deformasi.

\subsection{Pengaruh Gaya Damping $\left\{f_{D}\right\}$}

$\left\{\mathbf{f}_{\mathrm{D}}\right\}=[\mathbf{C}] .\{\mathbf{u ́}\}$

Dimana:

$[\mathrm{C}]=$ Matriks damping

$\{\mathfrak{u}\}=$ Vektor kecepatan

\section{Periode Getar Bangunan}

Berdasarkan prinsip d'Alembert maka harga persamaan gerak diselesaikan dengan meninjau keadaan Undamped Free Vibrations, seperti pada persamaan berikut:

$\{\mathrm{P}(\mathrm{t})\}=\{0\} ; \quad[\mathrm{C}]=[0]$

$[\mathrm{m}] \cdot\{\ddot{u}\}+[\mathrm{k}] \cdot\{\mathrm{u}\}=[0]$

$$
\{\mathrm{u}\}=\{\dot{u}\} \mathrm{f}(\mathrm{t})
$$

Dimana:

$\{\mathrm{u}\}=$ perpindahan absolut

$\{u ́\}=$ mode shape :ragam getaran )

$\mathrm{f}(\mathrm{t})=$ amplitudo yang merupakan fungsi waktu

$\mathrm{f}(\mathrm{t})=\sin : \omega \mathrm{t}+\alpha)$

$\{\mathrm{u}\}=\{\dot{u}\} \sin : \omega \mathrm{t}+\alpha)$

Jadi

$[\mathrm{k}] \omega^{2}\{\dot{u}\}-[\mathrm{M}]\{\dot{u}\}=0\{\dot{u}\} \neq 0$

Dinamakan persamaan karakteristik eigen problem dan merupakan persamaan simultan. Persamaan ini dapat diselesaikan apabila harga $\quad u_{1,2,3,4 \ldots \mathrm{N}}$ harus ada.

$\left|[\mathbf{k}]-\boldsymbol{\omega}^{2}[\mathbf{m}]=\mathbf{0}\right|$

\section{Pola Ragam Bangunan (Mode Shape) dan Frekuensi}

Mode shape adalah jenis atau pola ragam akibat pergoyangan pada struktur bangunan. Mode ini merupakan fungsi dari properti dinamik dari struktur yang bersangkutan diantaranya massa dan kekakuan tingkat, dan bebas dari pengaruh waktu dan frekuensi getaran.

Jika sistem $\mathrm{N}$ DOF maka polinomial derajat $\mathrm{N}$ dengan $\mathrm{N}$ solusi tunggal didapat:

Frekuensi $\longrightarrow \omega_{1,2,3}$ dan seterusnya

Mode shape $\longrightarrow \Phi_{1,2,3}$ dan seterusnya

$\omega$ dan $\Phi$ merupakan sifat dinamis (dynamic characteristic) dari struktur MDOF.
Periode getar alami struktur adalah:

$\mathrm{T}=\frac{2 \pi}{\omega}$

Jika disusundalam bentuk matriks:

$$
\begin{gathered}
\{\omega\}=\left\{\begin{array}{c}
\omega_{1} \\
\omega_{2} \\
\ldots \\
\omega_{\mathrm{n}}
\end{array}\right\},[\phi]=\left[\phi_{1} \phi_{1} \phi_{2} \phi_{3} \ldots \phi_{\mathrm{n}}\right]= \\
{\left[\begin{array}{cccc}
\phi_{11} & \phi_{12} & \ldots & \phi_{1 \mathrm{n}} \\
\phi_{21} & \phi_{22} & \ldots & \phi_{2 \mathrm{n}} \\
\ldots & \ldots & \ldots & \ldots \\
\phi_{\mathrm{n} 1} & \phi_{\mathrm{n} 2} & \ldots & \phi_{\mathrm{nn}}
\end{array}\right],\{\mathrm{T}\}=\left\{\begin{array}{c}
\mathrm{T}_{1} \\
\mathrm{~T}_{2} \\
\ldots \\
\mathrm{T}_{\mathrm{n}}
\end{array}\right\}} \\
\text { dimana harga: } \\
\begin{array}{l}
\omega_{1}<\omega_{2}<\omega_{3}<\omega_{\mathrm{n}} \\
\mathrm{T}_{1}>\mathrm{T}_{2}>\mathrm{T}_{3}>\mathrm{T}_{\mathrm{n}}
\end{array}
\end{gathered}
$$

Respon perpindahan struktur akibat percepatan tanah identik dengan respon struktur terjepit pada tumpuannya yang memikul beban luar sebesar massa lantai dikalikan percepatan tanah, sehingga gerakan tanah dapat diganti dengan gaya gempa efektif :2.5.8 ).

$[\mathrm{m}] \cdot[\phi] \cdot\{\ddot{u}\}+[\mathrm{c}] \cdot[\phi] \cdot\{\dot{u}\}+$ $[\mathrm{k}] .[\phi] .\{\mathrm{u}\}=\mathrm{peff}(\mathrm{t})(3.26)$

$\left[\phi_{n}\right]^{\mathrm{T}} \cdot[\mathrm{m}] \cdot[\phi] \cdot\{\ddot{u}\}=\quad[\mathrm{c}] \cdot[\phi] \cdot\{\dot{u}\}+$ $\left[\phi_{n}\right]^{\mathrm{T}} \cdot[\mathrm{k}] \cdot[\phi] \cdot\{\mathrm{u}\}$

$\mathrm{m}^{*}{ }_{\mathrm{n}} \cdot \ddot{u}_{\mathrm{n}}+\mathrm{c}^{*}{ }_{\mathrm{n}} \cdot \dot{u}_{\mathrm{n}}+\mathrm{k}^{*}{ }_{\mathrm{n}} \cdot \mathrm{u}_{\mathrm{n}}=\mathrm{p}^{*}{ }_{\mathrm{n}}$

dimana:

$\mathrm{m}^{*}{ }_{\mathrm{n}}=\left[\phi_{\mathrm{n}}\right]^{\mathrm{T}} \cdot[\mathrm{m}] \cdot[\phi]$

$\mathrm{c}^{*}{ }_{\mathrm{n}}=\left[\phi_{\mathrm{n}}\right]^{\mathrm{T}} \cdot[\mathrm{c}] \cdot[\phi]=2 \gamma_{\mathrm{n}} \cdot \omega_{\mathrm{n}} \cdot \mathrm{m}^{*}{ }_{\mathrm{n}}$

$\mathrm{k}^{*}{ }_{\mathrm{n}}=\left[\phi_{\mathrm{n}}\right]^{\mathrm{T}} \cdot[\mathrm{k}] \cdot[\phi]=\omega_{\mathrm{n}}^{2} \cdot \mathrm{m}^{*}{ }_{\mathrm{n}}$

$\mathrm{p}^{*} \mathrm{n}=\left[\phi_{\mathrm{n}}\right]^{\mathrm{T}} \cdot p$ eff $(\mathrm{t})$

Berdasarkan persamaan (2.27) untuk struktur MDOF, kontribusi setiap mode ditunjukan oleh besarnya partisipasi setiap mode yang dinyatakan sebagai berikut:

$\Gamma_{\mathrm{n}}=\frac{\mathrm{p} * \mathrm{n}}{\mathrm{m} * \mathrm{n}}=\frac{[\phi]_{\mathrm{n}} \cdot[\mathrm{m}]}{\left[\phi_{\mathrm{n}}\right]^{\mathrm{T}} \cdot[\mathrm{m}] \cdot \phi_{\mathrm{n}}}$

Karena matriks massa adalah matriks diagonal, maka persamaan diatas juga dapat ditulis dalam bentuk:

$\Gamma_{\mathrm{xm}}=\frac{\sum_{\mathrm{i}=1}^{\mathrm{m}} \mathrm{m}_{\mathrm{i}} \phi_{\mathrm{im}}}{\sum_{\mathrm{i}=1}^{\mathrm{m}} \mathrm{m}_{\mathrm{i}} \phi 2_{\mathrm{im}}}=\frac{\sum_{\mathrm{i}=1}^{\mathrm{m}} \frac{\mathrm{w}_{\mathrm{i}}}{\mathrm{g}} \phi_{\mathrm{im}}}{\sum_{\mathrm{i}=1}^{\mathrm{m}} \frac{\mathrm{w}_{\mathrm{i}}}{\mathrm{g}} \phi 2_{\mathrm{im}}}$

\subsection{Penggunaan Model Kombinasi}

Ada beberapa model kombinasi yang digunakan untuk menentukan nilai puncak perpindahan atau jumlah dari respon ragam 
suatu struktur. Penjumlahan respon ragam itu dapat dilakukan dengan beberapa model kombinasi perhitungan, yaitu:

Kombinasi kuadratik lengkap (Complete Quadratic Combination atau CQC) (Sumber: Chopra, 2007)

$$
\begin{gathered}
r_{0} \approx \sqrt{\sum_{i=1}^{n} \sum_{n=1}^{n} \rho_{\text {in }} r_{i o} r_{n 0}} \\
\rho_{\text {in }}=\frac{8 \xi^{2}\left(1+\beta_{\text {in }}\right) \beta_{\text {in }}{ }^{3 / 2}}{\left(1-\beta_{\text {in }}{ }^{2}\right)^{2}+4 \xi^{2} \beta_{\text {in }}\left(1-\beta_{\text {in }}{ }^{2}\right)^{2}} \\
\xi=\text { harga redaman }(\text { damping }), \\
\beta_{\text {in }}=\frac{\omega_{i}}{\omega_{n}}
\end{gathered}
$$

Akar Jumlah Kuadrat (Square Root of the Sum of the Squares atau SRSS) (Sumber: Chopra, 2007)

$r_{0} \approx \sqrt{\sum_{n=1}^{n} r_{n o}^{2}}$

Menurut SNI 03-1726-2002 \&03-17262012 metode CQC digunakan apabila struktur gedung mempunyai waktu getar alami yang berdekatan, yaitu selisih nilainya kurang dari $15 \%$. Sedangkan metode SRSS digunakan apabila struktur gedung mempunyai waktu getar alami yang berjauhan.

ABSSUM :Absolut Sum )

(Sumber: Chopra, 2007)

$$
r_{0} \leq \sum_{n=1}^{n}\left|r_{n o}\right|
$$

\subsection{Desain Respon Spektra}

Setelah nilai-nilai koefisien pergerakan tanah didapat, maka nilai-nilai tersebut di plot kedalam bentuk respon spektra. Desain respon spektrum harus memenuhi persyaratan sebagai berikut:

Untuk periode lebih kecil dari $T_{0}$, desain percepatan respon spektra $S_{a}$ harus diambil dari persamaan

$$
S_{a}=S_{D S}\left(0,4+0,6 T / T_{0}\right)
$$

Untuk periode yang lebih besar atau sama dengan $T_{0}$ atau kurang dari sama dengan $T s$, desain percepatan respon spektra $S_{a}$ diambil setara $S_{D S}$
Untuk periode yang lebih besar dari $\mathrm{T}_{\mathrm{s}}$ dan kurang dari sama dengan $T_{L}$, nilai percepatan respon spektra $S_{a}$ harus diambil berdasarkan persamaan 11.4-6

$$
\mathrm{S}_{\mathrm{a}}=\mathrm{S}_{\mathrm{D} 1} / \mathrm{T}
$$

Untuk periode lebih besar dari $T_{L}$, nilai percepatan respon spektra $S_{a}$ harus diambil berdasarkan persamaan 11.4-7

$$
\mathrm{S}_{\mathrm{a}}=\mathrm{S}_{\mathrm{D} 1} \mathrm{~T}_{\mathrm{L}} / \mathrm{T}^{2}
$$

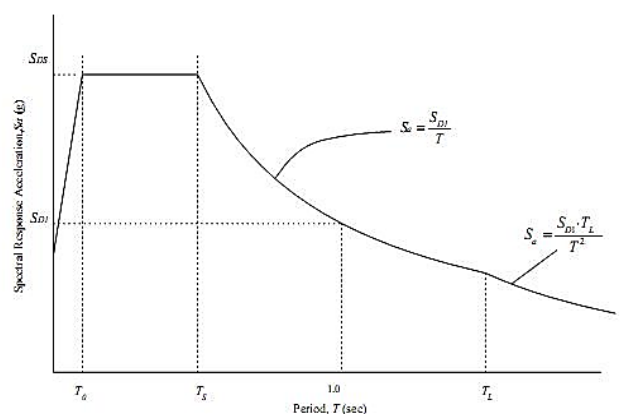

Gambar 3.8. Desain respon spektra menurut ASCE 7-10

Secara garis besar tahapan dalam mendesain dan menganalisis struktur beban Dinamik adalah:

1. Menentukan geometri model struktur

2. Mendefinisikan data struktur

- Data material

- Data penampang

- Data beban

- Data kombinasi pembebanan

3. Menetapkan data ke model struktur

- menetapkan data penampang

- Menetapkan beban yang bekerja

4. Memeriksa input data

5. Melakukan analisis

6. Melakukan desain struktur

7. Melakukan desain ulang bila perlu

\section{KESIMPULAN}

Secara garis besar tahapan dalam mendesain dan menganalisis struktur beban Dinamik adalah:

1. Menentukan geometri model struktur

2. Mendefinisikan data struktur

- Data material

- Data penampang

- Data beban

- Data kombinasi pembebanan

3. Menetapkan data ke model struktur 
- menetapkan data penampang

- Menetapkan beban yang bekerja

4. Memeriksa input data

5. Melakukan analisis

6. Melakukan desain struktur

7. Melakukan desain ulang bila perlu

\section{DAFTAR PUSTAKA}

ASCE/SEI 7-10, 2010, Minimum Design Loads For Buildings and Other Structures, Structural Engineering Institute of the American Society of Civil Engineers, Reston, Virginia.

Chopra, A.K., 2007, Dynamics of Structures, Theory and Applications To Earthquake Engineering, Third Edition. Pearson Education, Inc.

Departemen Pekerjaan Umum, 1983, Peraturan Pembebanan Indonesia Untuk Gedung 1983, Yayasan Lembaga Penyelidikan Masalah Bangunan: Bandung.

Departemen Pekerjaan Umum, 2002, Tata Cara Perencanaan Ketahanan Gempa Untuk Bangunan Gedung, SNI 03-17262002, Penerbit PU Jakarta: Jakarta.

Departemen Pekerjaan Umum, 2002, Tata Cara Perhitungan Struktur Beton Untuk Bangunan Gedung, SNI 03-2847-2002, Penerbit PU Jakarta: Jakarta

Kementrian Pekerjaan Umum, 2010, Buku Penggunaan Peta Indonesia 2010, Penerbit PU: Jakarta

Naeim, F., 2002, The Seismic Design Handbook, $2^{\text {nd }}$ Edition.

Departemen Pekerjaan Umum, 2002, Tata Cara Perhitungan Struktur Beton Untuk Bangunan Gedung, SNI 03-2847-2012, Penerbit PU Jakarta: Jakarta. 